\title{
A CORRELATIONAL STUDY ON THE EFFECTIVENESS OF TRAINING PROGRAMS FOR INCREASING THE MOTIVATIONAL LEVEL OF EMPLOYEES
}

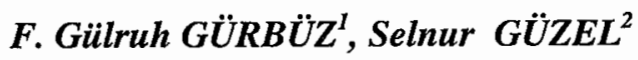 \\ ${ }^{\prime}$ Marmara Üniversitesi, İ.̇.B.F. İngilizce İşletme Bölümü, Yardımcı Doçent Dr. \\ ${ }^{2} M B A$ Student
}

Özet: Günümüzde tüm işletmelerin başartl olabilmesi, dünya pazarlarında rekabet edebilmesi için iyi eğitilmis, verimli çalışan işgörenlere ihtiyacı olduğu herkes tarafindan bilinen bir gerçektir. Durum böyle olunca işletmelerin hem işletme içi eğitim programlarina yeterince önem vermeleri hem de yöneticilerin işgörenleri daha çok çalışma ve başartl olma yönünde güdülemeleri gerekmektedir. Bu araştırmanın amacı işletmede, işgörenlere yönelik düzenlenen eğitim programlan ile işgörenlerin iş motivasyonu arasında arasında bir ilişkinin olup olmadığını araşstımaktır. Bu düş̧ïnceden yola çıkarak egitime tabi tutulmuş isgörenlerin is motivasyonlartnin, eğitime tabi tutulmayanlara nazaran daha fazla olacağ varsayımında bulunulmuştur. İstanbul'da bilgi teknolojilleri sektörïin̈̈n önde gelen firmalarndan birinde bir anket çalışması düzenlenmiş, elde edilen bulgular varsayımlarımızı destekleyici yönde olmuştur.

\section{INTRODUCTION}

Motivation plays a very important role in determining how successful we are in life. Most of the people who fail in life are not actually defeated; they simply give up before achieving what they want. And often they do not even know what they want, why they want it, or how to get it. Since management is the process of getting productive work done with and through the efforts of other individuals, understanding the nature of human motivation is one key to successful management. While understanding the nature of motivation and some of its effects on people is very useful, the manager's challenge is to know how to create situations where motivation can work for them and for their organization.

In today's rapidly changing business environment, managers face greater challenges than before to maintain and sustain their position among the competitors. Increasingly, organizations are recognizing that a motivated work force with superior skills is one of the primary vehicles for sustaining competitive advantage. In order to compete in world markets, the companies must boost productivity and invest in a better trained and skilled workforce which, at the same time, are highly motivated to do their work productively. So, today's companies must give great importance to the subject of employee training and keep highly motivated and dedicated employees in the organization. Virtually all people -practitioners and scholars- have their own definition of motivation. One of the basic definition of motivation is "the set of forces that causes people to behave in certain ways" [1]. Motivation is also defined as "all those inner striving conditions described as wishes, desires, drives, etc... It is an inner state that activates or moves. Motivation cannot be seen, heard or felt but can only be inferred from behavior. In other words, we can judge how motivated a person is only by observing his or her behavior; managers can not measure motivation directly because it is unobservable" [2]. The manager's most important work is to motivate and direct human behavior.

Creating conditions under which these kinds of behavior can flourish is the job of the effective managers. These conditions determine the extent to which motivation will occur [3]. So from the manager's viewpoint, the objective is to motivate people in ways that are in the organization's best interest.

The importance of motivation can be illustrated by the following model [4]:

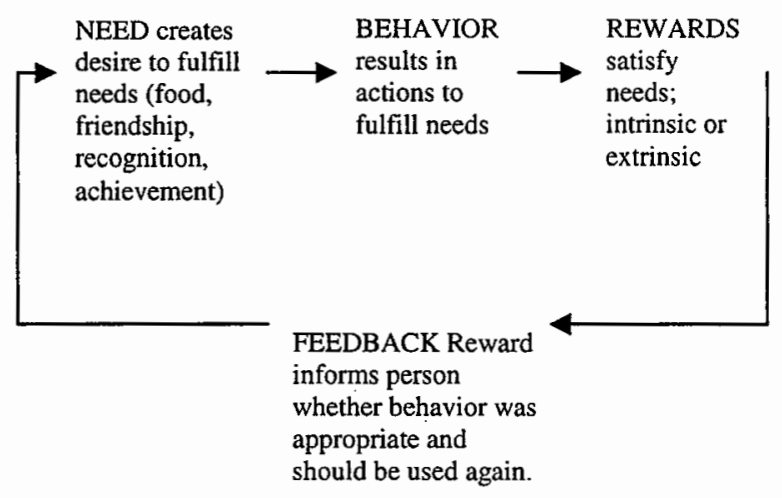

Figure.1: A Model of Motivation 
People have basic needs, such as food, achievement or monetary gain, that translate into an internal tension that motivates specific behaviors with which to fulfill the need. To the extent that the behavior is successful, the person is rewarded in the sense that the need is satisfied. The reward also informs the person that behavior is appropriate and can be used again in the future.

Rewards are of two types: intrinsic and extrinsic.

Intrinsic rewards are received as a direct consequence of a person's actions. The completion of a complex task may bestow a pleasant feeling of accomplishment. Extrinsic rewards are given another person, typically a manager, and include promotions and pay increases. The importance of motivation as illustrated by this model is that it can lead to behaviors that reflect high performance within organizations.

As we have mentioned before, motivation is vital to all organizations and hence, to their managers. Often the difference between highly effective organizations and less effective ones lies in the motivational profiles of their members. So managers need to understand the nature of individual motivation, especially as it applies to work situations.

One of the manager's primary tasks is to motivate people in the organization to perform at high levels. This means getting them to work hard, come to work regularly, and make positive contributions to the organization's mission. But job performance depends on ability and environment as well as on motivation. Victor $\mathrm{H}$. Vroom, in his book 'work and motivation', explained this relationship as:

$$
P=f(M, A, E)
$$

where $\mathrm{P}=$ performance, $\mathrm{M}=$ motivation, $\mathrm{A}=$ ability, and $\mathrm{E}=$ environment. To reach high levels of performance, an employee should have a desire to do the job (motivation), be able to do the job (ability), and have the materials and equipment needed to do the job (environment). A deficiency in any one of these areas will hurt performance. A manager thus should strive to ensure that all three conditions are met [5]. While understanding the nature of motivation and some of its effects on people is very useful, even more important is that managers should know how to create situations where motivation can work for them and for their organization.

\section{I. OBJECTIVES OF THE STUDY}

The aim of this research is to explore the relationship between motivation and training and if training can be used as a motivational tool for effective management. Research was conducted in a company operating in information technologies sector in İstanbul. The specific research objectives can be summarized as follows: To identify the factors effective in the motivational level of employees, to learn the employees'opinions of training programs applied in the organisation and their effectiveness and finally determine if there is any correlational relationship between training programs and motivational level of employees.

Neither the effectiveness of each training program in the organisation nor the motivational differences among trained and non-trained employees have been specifically investigated. Instead overall training facilities relating to the training process in the organisation has been investigated through the training test.

\section{THEORETICAL FRAMEWORK}

We have mentioned that, in order to compete in world markets, the companies must boost productivity and invest in a better trained and skilled workforce, which at the same time, highly motivated to get productive work done. Training and development activities are planned programs of organizational improvement undertaken to bring about a relatively permanent change in employee knowledge, skills, attitudes or social behavior. However, sometimes the need for training and development may not be clear to employees, and to the organization as well. The critical point here is to well define the goals and objectives of the training and development effort depending on the different organizational goals and strategies applied for.

So, the goals and objectives of the training and development effort need to be identified early in the training process. Wexley and Latham have developed a $3 \times 3$ matrix to suggest what type of training might be indicated, depending on the goals sought and strategies favored in Table.1 [6].

Using the table, if the organization wishes to increase motivation, then an appropriate strategy that is behavior based, would involve coaching and behavior modeling (column "motivation" and row "Behavioral"). Similarly, if the employer wished to increase job skills, using a cognitive or intellectual approach, then lectures, audiovisual aids, case study, and computer based training would all be reasonable approaches.

Training is neither the only vehicle for developing people, nor is an appropriate solution to every organizational problem. But it is evident that training is an investment in current and future employee performance. So organizations should consider whether a formal 
training program is the best possible strategy to address the particular goal(s) at hand (increasing self awareness, job skills, motivation).

Table.1: Goals And Strategies For Training And Development (T\&D)

\section{GOALS of T\&D}

\begin{tabular}{|c|c|c|c|}
\hline & $\begin{array}{l}\text { Self- } \\
\text { Awareness }\end{array}$ & Job Skills & Motivation \\
\hline 总 & \begin{tabular}{|l|}
-Career \\
development \\
-Management \\
role theory \\
-Need for \\
achievement \\
-Double-loop \\
learning \\
-Sensitivity \\
training \\
-Self directed \\
management \\
development \\
-Transactional \\
analysis \\
\end{tabular} & $\begin{array}{l}\text {-Orientation training } \\
\text { and socialization of } \\
\text { new employees } \\
\text {-Lecture } \\
\text {-Audiovisual } \\
\text {-Case study } \\
\text {-The incident process } \\
\text {-Job aids } \\
\text {-Computer based } \\
\text { training } \\
\text {-Teleconferencing } \\
\text {-Corporate classrooms } \\
\text { colleges } \\
\text {-Seminars and } \\
\text { workshops } \\
\end{array}$ & $\begin{array}{l}- \text { Role } \\
\text { motivation } \\
\text { theory } \\
\text {-Need for } \\
\text { achievement } \\
\text {-Training } \\
\text {-Survey } \\
\text { Feedback }\end{array}$ \\
\hline 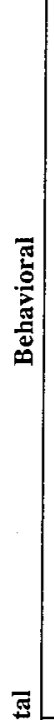 & $\begin{array}{l}\text {-Interactive } \\
\text { skills training }\end{array}$ & $\begin{array}{l}\text {-On the job training } \\
\text {-Apprenticeship } \\
\text {-Programmed } \\
\text { instruction } \\
\text {-Equipment simulators } \\
\text {-Computer-assisted } \\
\text { instruction } \\
\text {-Rational manager } \\
\text { training } \\
\text {-Conference } \\
\text { discussion } \\
\text {-Assesment centers } \\
\text {-Role playing } \\
\text {-Management games } \\
\text {-Grid seminors } \\
\text {-Leadr-member } \\
\text { exchange } \\
\text {-Junior boards } \\
\text {-Understudy } \\
\text { assignments } \\
\text {-Mentoring } \\
\end{array}$ & $\begin{array}{l}\text {-Coaching } \\
\text {-Behavior } \\
\text { modelling }\end{array}$ \\
\hline 节 & -Leader match & & $\begin{array}{l}\text {-Job rotation } \\
\text {-Behavior } \\
\text { modification }\end{array}$ \\
\hline
\end{tabular}

So, training of an employee as a need to be satisfied, is a mean to improve productivity, develop employee's skill levels, solve organizational problems, and create more loyal workforce. In a company, where effective training programs are given to employees, the motivational level of employees, which is to be assessed through analyzing different motivation factors, is expected to be high and training together with other motivational factors must play an important role in increasing the overall employee motivation. The primary interest of this study is to investigate if there is any correlational relationship between training programs and motivational level of employees.

\section{HYPOTHESIS}

On the basis of these arguments, this hypothesis (Ha) was developed:

$\mathrm{Ha}$ : Employees who receive effective training programs will express higher levels of job motivation than employees who do not receive effective training programs.

\section{THE RESEARCH DESIGN DETAILS}

The purpose of this research project was to establish a relationship between the independent variable of training and the dependent variable of motivation. In addition, the relationship between motivation and the independent demographic variables were examined, rather than trying to establish causal relationships between them. Thus, this project was a correlational rather than a causal study.

As this research project attempted to analyze the relationship between the dependent and independent variables, it was analytical in nature. It does not purport prediction; on the contrary it strives to investigate what is already in there.

The data for this project were collected just for once. No previous research has been done in the organization, and no subsequent extention of the research has been contemplated. Since we were interested in ascertaining the degree of job motivation of natural employees, the unit of analysis for this project was each individual employee. We analyzed the data gathered from each individual and treated each employee's response as an individual data source.

\section{V.1. Population and Sample}

The population for the survey was composed of employees in various divisions within a company in İstanbul operating in information technologies sector. The population consisted of 445 full-time employees and a questionnaire consisting of 40 items was administered to a sample of 100 employees from different seniority levels, selected through a convenience sampling method. The 
sample was chosen at random and most readily available full-time employees from different occupational groups and seniority levels were asked to voluntarily participate in the study.

\section{V.2. Data-Collection Methods}

The questionnaire for the study was personally administered on a working day. The subjects of the sample were division managers, coordinators, supervisors, assistants and office clerks. The sample was composed of $62 \%$ women and $38 \%$ men. These employees differed on the basis of age, $65 \%$ were between $25-35,18 \%$ were below $25,15 \%$ were between $36-45,1 \%$ between $46-55$ and $1 \%$ over $55.59 \%$ had university education, $13 \%$ had high school education and $28 \%$ had master's degree. $34 \%$ of the employees indicated that they had been working in the organization between $2-5$ years, while $28 \%$ less than 1 year, $19 \%$ between $1-2$ years, $13 \%$ between $5-10$ years and only $6 \%$ were working for more than 10 years. In addition, $46 \%$ of the employees indicated that their total work experience was less than 5 years, while $30 \%$ between 5-10 years, $19 \%$ between $11-15$ years, $1 \%$ between $16-20$ years and only $4 \%$ were more than 20 years.

\section{V.3. Variables and Measures}

The variable of primary interest to this research is the dependent variable of motivation. In addition, the effects of demographic variables on the motivational level were investigated in a more informative and descriptive manner.

The 40-item questionnaire tapped five personal information items: age, gender, education, number of years worked in the organization,total job experience. These were measured by single items. The dependent variable, motivation was measured through multiple items on a five-point Likert Scale. The independent variable, training programs directed to employees was again measured by a five point Likert Scale.

\section{V.3.1. Motivation}

In an attempt to understand what kinds of motivators are likely to evoke productive behaviors in individuals, different dimensions that were concerned primarily with work environment and dimensions concerned primarily with the job itself were analyzed. Each of these factors were tapped through 25 questions and the overall motivation level of the employees are computed by adding each factor's score. (See Appendix)

Questions related with the factors measuring motivation concerned primarily with the work environment:

Factors

Question number

Policies and administration

$9,23,2,11,20,21$

Supervision

12

Working conditions

$18,4,10,14$

Interpersonal relations

Money,status,security

$1,7,16$

Questions related with the factors measuring motivation primarily with the job itself :

$\underline{\text { Factors }}$

Question number

Achivement

6

Recognition for accomplishment

8

Challenging work

Increased responsibility

Growth and development

17

\section{V.3.2. Training Programs}

For understanding the employee's opinions of training programs and determine their effectiveness, a questionnaire consisting of 10 items were prepared. Each item attempted to understand a different aspect of training supplied in the company and the employees' pleasure with that aspect. Questions relating to training and development programs, technical and expertise training, the management attitudes toward training programs, overall training facilities relating to training process, the content of training programs, methods of assessing training needs of employees, employee's own training needs, trainers, time and scope of training were analyzed.

Effective training programs have been interpreted as high scores obtained from each training item explaining the extent of employees' pleasure towards the training aspects. The effectiveness of each training program in the organisation has not been specifically investigated. Instead overall training facilities relating to the training process in the organisation and the employees'overall pleasure towards the organisational training facilities have been investigated through the training questionnaire. (See Appendix) 


\section{V.4. Data Analysis Methods}

In the first place, frequency distributions were used to describe the sample. Then Cronbach's alpha was established separately for the dependent and independent variable. For the hypothesis, postulating the difference in the mean job motivation scores between the employees who were directed to effective training programs and who were not, t-test was done. The impact of demographic variables on the dependent variable were also tested. To test the effect of gender t-test was used. For the other demographic variables such as age, education, number of years worked in the organization and total work experience, Analysis of Variance (ANOVA) was used. While testing the variable age, Scheffe's test was also used in addition to the ANOVA.

\section{RESULTS}

Research statistical evaluation was carried out with a statistical program for Ms Windows. Significance level of .05 had been taken into consideration during statistical analysis.

The dependent variable, job motivation (the total motivation score) had a mean of 83,13 and a standard deviation of 15,23 .

For the specification of reliabilities, inter-item coefficients had been computed for both motivation and training questionnaire. In this evaluation, in order to decide which items in the questionnaire should be retained in the further statistical analysis, three criteria were used; a) recomputation of Cronbach's alpha after the extraction of the items, b) the corrected itemtotal correlation, and c) square multiple correlation.

An item analysis was conducted to understand whether or not all items of motivation test should be retained in further analysis. All respondents $(\mathrm{N}=100)$ were included in this analysis. Reliability analysis was carried out by correlating each relevant item with respective total scale (excluding the item itself) This analysis indicated that no item in the full scale correlated lower than $r=0.9101$ and Cronbach's alpha for full scale correlated $\mathrm{r}=0.9151$. The same analysis had been conducted for training test, and analysis indicated that no item in the full scale correlated lower than $r=0.9320$ and Cronbach's alpha for full scale correlated $\mathrm{r}=0.9412$.

$\mathrm{H}_{0}$ : There is no difference between employees who receive effective training programs and who do not receive in terms of their job motivation levels.

Ha: Employees who receive effective training programs will express higher levels of job motivation than employees who do not receive effective training programs.

To test for statistical significance, T-test was established. The T-test is used to compare the means of two groups.An Independent Sample T-Test is used with groups which do not share pairs of scores. Since we are comparing the means of two groups, weshould identify the variable that is being used to identify group members. The grouping variable is commonly known as the independent variable and it is a categorical variable. We defined group 1 as employees who received effective training programs, whose total training scores were greater or equal to 25 , and group 2 as employees who did not receive effective training programs whose total training scores were less than 25. (After analyzing the frequencies, total training scores were maximum 50 and minumum 10 , with a mean of 33,070 and a standard deviation of 8,335 ). So effective training programs has been interpreted as high scores obtained from each training item explaining the extent of employees' pleasure towards the training aspects. Here we assume that high scores obtained from the questionnaire indicate the employee's pleasure towards the organisation's overall training facilities. After that we identified the Test variable, which is also known as the dependent variable, the job motivation. This should be the continious variable we wish to compare the two groups.

It showed significant differences between the mean score of 86,05 for the employees who received effective training programs and 66,53 for the employees who did not receive $(p=0.000)$. Thus the null hypothesis was rejected at 0.05 significance level and the alternative hypothesis was accepted. This showed that job motivation scores for the individuals who did not receive effective training programs were really lower than the ones who received. Table. 2 below shows this research result:

Table. 2: Independent t-Test between Training and Job Motivation

\begin{tabular}{|l|l|l|l|l|}
\hline $\begin{array}{l}\text { Independent } \\
\text { t-test between } \\
\text { Training and } \\
\text { Job } \\
\text { Motivation } \\
\text { Groups }\end{array}$ & $\begin{array}{l}\text { Number } \\
\text { of Cases }\end{array}$ & Mean & $\begin{array}{l}\text { 2-tailed } \\
\text { Significance }\end{array}$ & $\begin{array}{l}\text { Significance } \\
\text { level }\end{array}$ \\
\hline $\begin{array}{l}\text { Receive } \\
\text { effective } \\
\text { training } \\
\text { programs } \\
\text { Total training } \\
\text { scores >25 }\end{array}$ & 85 & 86,0588 & 0,000 & 0,05 \\
\hline $\begin{array}{l}\text { Do not receive } \\
\text { effective } \\
\text { training } \\
\text { programs } \\
\text { Total training } \\
\text { scores <25 }\end{array}$ & 15 & 66,5333 & & \\
\hline \begin{tabular}{l} 
Mean Difference \\
\hline
\end{tabular} & & & & \\
\hline
\end{tabular}


As an additional information, the impact of demographic factors on the job motivation level was also examined at the significance level of 0.05 . The $T$-test for gender indicated that gender played no role on the job motivation level.

Table.3: Independent t-Test for Gender and Job Motivation

\begin{tabular}{|l|c|c|c|c|}
\hline Groups & $\begin{array}{c}\text { Number } \\
\text { of Cases }\end{array}$ & Mean & $\begin{array}{c}\text { 2-tailed } \\
\text { significance }\end{array}$ & $\begin{array}{c}\text { Significance } \\
\text { level }\end{array}$ \\
\hline Female & 62 & 82,7581 & 0,685 & 0,05 \\
\hline Male & 38 & 83,7368 & & \\
\hline
\end{tabular}

ANOVA tests for education and total work experience showed that these variables played no role on job motivation. No groups are significantly different at the 0,05 level. ANOVA for age $(\mathrm{p}=0,0214)$ and number of years worked for the organization $(p=0,0336)$ indicated that employees differed on the basis of these variables according to their job motivation scores. The employees below 25 years old had a mean score of 87,2 , while the ones in the second group between 25-35 years of age had a mean score of 79,7 . The third group of individuals between 36-45 years of age had a mean score of 92,5 and the fourth group of individuals between 46-55 years of age had a mean score of 77,00. Finally the last group, which has one member above 55 years of age had a mean score of 97,00 .

Table.4: One Way ANOVA between Age and Job Motivation

\begin{tabular}{|c|c|c|c|c|}
\hline Groups & $\begin{array}{c}\text { Number } \\
\text { of Cases }\end{array}$ & Mean & F Probability & $\begin{array}{c}\text { Significance } \\
\text { level }\end{array}$ \\
\hline $\begin{array}{c}\text { Less than 1 } \\
\text { year }\end{array}$ & 28 & 82,2500 & 0,0336 & 0,05 \\
\hline $\begin{array}{c}\text { Between 1 -2 } \\
\text { years }\end{array}$ & 19 & 75,5789 & & \\
\hline $\begin{array}{c}\text { Between 2-5 } \\
\text { years }\end{array}$ & 34 & 83,5882 & & \\
\hline $\begin{array}{c}\text { Between 5-10 } \\
\text { years }\end{array}$ & 13 & 92,0000 & & \\
\hline $\begin{array}{c}\text { More than 10 } \\
\text { years }\end{array}$ & 6 & 89,3333 & & \\
\hline
\end{tabular}

Besides, ANOVA results for number of years worked for the organization indicated that employees who are working between 5-10 years for the organization had a mean score of 92,00 while employees who are working between 1-2 years for the organization had a mean score of 75,57 .
Table 5: One Way ANOVA Between Educational Level and Job Motivation

\begin{tabular}{|l|c|l|c|c|}
\hline Groups & $\begin{array}{l}\text { Number } \\
\text { of Cases }\end{array}$ & Mean & F Probability & $\begin{array}{l}\text { Significance } \\
\text { level }\end{array}$ \\
\hline $\begin{array}{l}\text { Below 25 } \\
\text { years }\end{array}$ & 18 & 87,2222 & 0,0214 & 0,05 \\
\hline $\begin{array}{l}\text { Between 25- } \\
\text { 35 years }\end{array}$ & 65 & 79,7231 & & \\
\hline $\begin{array}{l}\text { Between 36- } \\
\text { 45 years }\end{array}$ & 15 & 92,4667 & & \\
\hline $\begin{array}{l}\text { Between 46- } \\
\text { 55 years }\end{array}$ & 1 & 77,0000 & & \\
\hline $\begin{array}{l}\text { Above 55 } \\
\text { years }\end{array}$ & 1 & 97,0000 & & \\
\hline
\end{tabular}

Table 6: One Way ANOVA Between Total Work Experience and Job Motivation

\begin{tabular}{|l|c|c|c|c|}
\hline $\begin{array}{c}\text { Educational } \\
\text { Level }\end{array}$ & $\begin{array}{c}\text { Number } \\
\text { of Cases }\end{array}$ & Mean & F Probability & $\begin{array}{c}\text { Significance } \\
\text { level }\end{array}$ \\
\hline High School & 13 & 76,000 & 0,1116 & 0,05 \\
\hline University & 59 & 83,0169 & & \\
\hline $\begin{array}{l}\text { Master's } \\
\text { Degree }\end{array}$ & 28 & 86,6786 & & \\
\hline
\end{tabular}

Table 7: One Way ANOVA between Number of Years Worked for the Organization and Job Motivation

\begin{tabular}{|c|c|c|c|c|}
\hline Groups & $\begin{array}{c}\text { Number } \\
\text { of Cases }\end{array}$ & Mean & F Probability & $\begin{array}{c}\text { Significance } \\
\text { level }\end{array}$ \\
\hline $\begin{array}{c}\text { Less than 5 } \\
\text { years }\end{array}$ & 46 & 80,1304 & 0,1922 & 0,05 \\
\hline $\begin{array}{c}\text { Between 5-10 } \\
\text { years }\end{array}$ & 30 & 82,7333 & & \\
\hline $\begin{array}{c}\text { Between 11-15 } \\
\text { years }\end{array}$ & 19 & 89,7368 & & \\
\hline $\begin{array}{c}\text { Between 16-20 } \\
\text { years }\end{array}$ & 1 & 94,0000 & & \\
\hline $\begin{array}{c}\text { More than 20 } \\
\text { years }\end{array}$ & 4 & 86,5000 & & \\
\hline
\end{tabular}

Employees highest motivation scores were obtained from items relating to feeling respect for having a good job, getting along well with coworkers, steady employment, health benefits, and pleasure with the job. On the contrary, lowest scores were obtained from pay, degree of involvement in managerial decisions, promotion opportunities, fringe benefits and agreement with organization's objectives. For assessing the employees' opinions of the training programs and their effectiveness, the highest satisfaction scores obtained from the item investigating the pleasure with training programs' time where as the lowest scores obtained from the item investigating the training programs availability in cases of employees' personal demands. 


\section{DISCUSSION}

The major objective of this study was to investigate the concept of job motivation and its relationship with training programs. This research project was based on the claim that employees who received effective training programs would express higher levels of job motivation than employees who did not receive effective training programs. The present findings of the research indicate that this claim could be supported, since it was observed with the statistical tests that individuals who were not satisfied with the company's training and development facilities had really lower motivation scores than the employees who received effective training programs and reported high motivation scores. Here effective training programs has been interpreted as high scores obtained from each training item explaining the extent of employees' pleasure towards the training aspects. We assumed that high scores obtained from the test indicate the employees' pleasure towards the organisation's overall training facilities.

For the interpretation of this finding, employees were tested in a company via a 40 -item questionnaire. The item analysis and reliability tests were conducted to understand whether or not all items of motivation and training tests should be retained in further analysis. This analysis indicated that no item in the full scale in motivation test correlated lower than $r=0,70$ in Cronbach's alpha and should be retained in further analysis. Besides, all the demographic variables' (age, gender, education level, total years of work experience, number of years worked for the organization) effects on job motivation were investigated. The analysis indicated that there was no significant relationship for gender, educational level, and total work experience. However, when we compared the means between job motivation and age and number of years worked for the organization, job motivation means differed on the basis of these variables.

In this research project, the use of a convenience sampling method created certain deficiencies such as choosing the subject of the sample from only readily available full-time employees in various departments who voluntarily wanted to participate, instead of selecting them at random. It would be more reliable if a different sampling technique were used. We must also take into consideration the fact that the individual's position in the organization may effect the way he fills out the questionnaire. In many situations, especially in middle or top levels, reporting a high level of job motivation may be thought of as a socially desirable response and it is possible that, individuals have the tendency to give such responses.

Neither the effectiveness of any distinct training program in the organisation nor the motivational differences among trained and non-trained employees have been specifically investigated in this research. Instead employees' overall pleasure against the training facilities about the training process in the organisation has been investigated through the training test. Investigation of these aspects may be the scope of another study.

\section{CONCLUSION and RECOMMENDATIONS}

This study enables us to consider the effects of different aspects of the training programs and job motivation of employees. Most importantly, it shed light on the relationship between the job motivation level and effective training programs directed to employees.

We have discussed a number of items for measuring the employees' overall motivation levels. We have already taken into account the factors concerned primarily with work environment like working conditions, pay, interpersonal relations, policies and administration, supervision and factors concerned primarily with the job itself like increased responsibility, challenging work, growth and development and achievement.

However, motivation is not based on conscious, observable needs. Sometimes, there are unconscious or subconscious elements within individuals that cause them to be motivated. Individuals can sometimes be motivated by forces that they are not even aware of. We limited our research with the questionnaire items to reach the total motivation scores. We pointed out that to increase motivation, manager's can clarify employee's needs and define the outcomes available from the organization and ensure that each employee has the ability and support (training, time and equipment) to attain these outcomes. So, in effect, training is supposed to be used as a motivational tool or a strategy in the organization. Neither the needs of the employees nor the outcomes of the organization were measured in this study. Main aim was to find if effectively trained employees would express higher levels of job motivation or not.

For further research studies, it may be valid to use factor analysis for investigating the subdimensions of motivation and training variables. For administrative purposes, it is very useful to know which sections of an organization and which employees need training programs, learn the employees opinions about the training programs supplied by the company and analyze their effectiveness through investigating different aspects of training. The development of training test may contribute to this area and serve for investigating the effectiveness of training programs in Turkish companies with its practical usefulness. Besides, the development of motivation test may serve for the manager's desire to assess the motivational levels of employees through analyzing different motivation factors. However up to now, a few 
number of developed or adapted instruments to measure the relationship between motivation and training have been available in Turkish, and this study may contribute to this area and may fill this gap. Training and its improvement is a slow and long process which helps making a person more employable or promotable within the organization and teaches basic skills. Moreover, employee development helps employees progress with growing organizations and helps employees coping with changes in the business environment. So training and development facilities are a life-time process for organizations and employees. On the other hand, motivation can be incrased quickly by appropriate strategies and tools. It can be concluded that job performance is the building block for the success of companies and its basic components of ability and motivation is covered in this research study. The aim of this thesis was to find out effectiveness of training programs for increasing the motivational level of employees and show that training has a positive effect in improving the motivational level of employees. In order to compete in world markets, the companies must boost productivity and invest in a better-trained and skilled workforce which, at the same time, highly motivated to get productive work done. So, today's companies must give great importance to the subject of employee training and keep highly motivated, dedicated employees in the organization.

\section{REFERENCES}

[1] STEERS, R.M., PORTER, L.W., Motivation and Work Behavior, $5^{\text {th }}$ Edition, McGraw Hill, 1991, p.5.

[2] IVANCEVICH, J.M.; DONNELLY JR.J.H.; GIBSON, J.L., Business Publication Inc., 1983, p.359.

[3] TIMM, P.R.; PETERSON, B.D., People At Work / Human Relations in Organizations, Second Edition, 1986, p.24.

[4] DAFT, RICHARD L., Management, The Dryden Press, 2000, p.535.

[5] VROOM, V.H., Work And Motivation, Wiley Pub, 1964, p.17.

[6] WEXLEY, K.N., LATHAM, G.P., Developing and Training Human Resources in Organizations, $2^{\text {nd }}$ Edition, Harper-Collins, New York, 1991. 


\section{APPENDIX}

Aşağıdaki sorularda size uygun olan bölümü işaretleyerek gösteriniz:

1. Yaş:

1- $25^{\prime}$ in altı 2- 25-35 aras1 3-36-45 arasi 4-46-55 aras1 5- 55' in üstü

2. Cinsiyet : 1-Kadın 2-Erkek

3. Eğitim Düzeyi: 1- Lise Mezunu 2- Üniversite Mezunu 3-Lisansüstü

4. Şimdiki İşyerinde toplam çalışılan yıl:

1- 1 yıldan az 2- 1-2 yıl arası 3-2-5 yıl arası 4- 5-10 yıl arası 5- 10 yıldan fazla

\section{Toplam iş tecrübeniz:}

1- 5 yıldan az 2-5-10 yıl arası 3-11-15 yıl arası 4- 16-20 yıl arası 5- 20 yıldan fazla

6. Aşağıda iş yaşamınızın çeşitli yönleri ile ilgili ifadeler bulunmaktadır. Her cümleyi dikkatle okuyarak cümlede belirtilen ifadenin çalıştığınız işletmedeki iş motivasyonunuzu belirleyen etkisini size uygun olan seçeneği işaretleyerek belirtiniz.

İş Motivasyonumu etkilemesi açısından:

\section{Yaptığım iş karşılığında aldığım ücretten}

Hiç memnun değilim Memnun değilim Kararsızım Memnunum Çok memnunum

2. İşletmede bana sürekli bir iş sağlanmasından

Hiç memnun değilim Memnun değilim Kararsızım Memnunum Çok memnunum

3. İşletmedeki görevim nedeniyle toplumda duyduğum saygınlıktan

Hiç memnun değilim Memnun değilim Kararsızım Memnunum Çok memnunum

\section{4. İşletmedeki fiziksel çalışma ortamından}

Hiç memnun değilim Memnun değilim Kararsızım Memnunum Çok memnunum

\section{5. İşletmedeki diğer çalışma arkadaşlarım ile uyumumdan}

Hiç memnun değilim Memnun değilim Kararsızım Memnunum Çok memnunum

\section{6. İşletmedeki terfi imkanlarından}

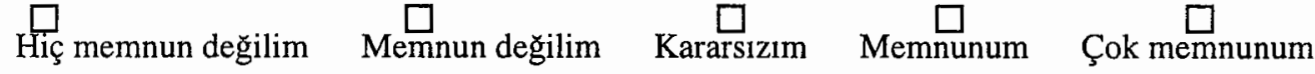


7. İşletmede ücret dışı yapılan yardımlardan

Hiç memnun değilim Memnun değilim Kararsızım Memnunum Çok memnunum

8. Yaptığım çalışmalar sonucu takdir edilmem ve duyduğum başarı hissinden

Hiç memnun değilim Memnun değilim Kararsızım Memnunum Çok memnunum

9. İșletme hedefleri ve kişisel hedeflerim arasındaki uyumundan

Hiç memnun değilim Memnun değilim Kararsızım Memnunum Çok memnunum

10. Yazılı bir is tanımının olması ve işletmedeki görev dağılımının belirginliğinden

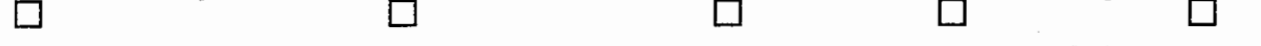

Hiç memnun değilim Memnun değilim Kararsızım Memnunum Çok memnunum

11. İşletmede uygulanan performans değerlendirme sisteminden

Hiç memnun değilim Memnun değilim Kararsızım Memnunum Çok memnunum

12. İşletmede amirim tarafından denetim altında tutulma derecemden

Hiç memnun değilim Memnun değilim Kararsızım Memnunum Çok memnunum

13. İşimi yaparken kendi yöntemlerimi kullanma ve kararlarımı uygulama derecemden

Hiç memnun değilim Memnun değilim Kararsızım Memnunum Çok memnunum

14. İşletmedeki tatil ve izin uygulamalarından

Hiç memnun değilim Memnun değilim Kararsızım Memnunum Çok memnunum

15. İşletmedeki yöneticiler arasındaki uyumdan

Hiç memnun değilim Memnun değilim Kararsızım Memnunum Çok memnunum

16. Yaptığım iş itibariyle hak ettiğim yetki düzeyi ve ünvanımdan

Hiç memnun değilim Memnun değilim Kararsızım Memnunum Çok memnunum

17. İş başarımı etkileyecek eğitim ve gelişme imkanlarından

Hiç memnun değilim Memnun değilim Kararsızım Memnunum Çok memnunum

18. İşletmedeki çalışma saatlerinden

Hiç memnun değilim Memnun değilim Kararsızım Memnunum Çok memnunum 
19. Yaptığım işte yaratıcılığımı kullanabilme düzeyimden

Hiç memnun değilim Memnun değilim Kararsızım Memnunum Çok memnunum

\section{0. İşletmedeki hekim ve sağlık hizmetlerinden}

Hiç memnun değilim Memnun değilim Kararsızım Memnunum Çok memnunum

21. İşletmede yönetimle ilgili kararlara katılabilme seviyemden

Hiç memnun değilim Memnun değilim Kararsızım Memnunum Çok memnunum

22. İşletmede ekip çalışmalaruna verilen önem derecesinden

Hiç memnun değilim Memnun değilim Kararsızım Memnunum Çok memnunum

23. İşletme yönetimi ile ilgili stratejilerin çalışanlara bildirilme seviyesinden

Hiç memnun değilim Memnun değilim Kararsızım Memnunum Çok memnunum

24. Görevim itibariyle aldığım sorumluluk miktarından

Hiç memnun değilim Memnun değilim Kararsızım Memnunum Çok memnunum

25. İşletmedeki görev tanmmmdan

Hiç memnun değilim Memnun değilim Kararsızım Memnunum Çok memnunum

7. Aşağıda çalıştığınız işletmede verilen eğitim ve kişisel gelişim programları ile ilgili ifadeler bulunmaktadır. Her cümleyi dikkatle okuyarak, cümlede belirtilen ifadenin çalıştı̆ınız işletmedeki uygulamasından ne derece memnun olduğunuzu ilgili bölümü işaretleyerek belirtiniz.

1. İşletmedeki iş başarısımı artırmaya yönelik eğitim programları uygulamalarından

Hiç memnun değilim Memnun değilim Kararsızım Memnunum Çok memnunum

2. İşletmedeki kişisel gelişime yönelik eğitim programları uygulamalarından

Hiç memnun değilim Memnun değilim Kararsızım Memnunum Çok memnunum

3. İşletmedeki uzmanlık ve teknik eğitim programları uygulamalarından

Hiçmemnun değilim Memnun değilim Kararsızım Memnunum Çok memnunum 
4. İşletme yönetiminin eğitim programlarının uygulanmasma yönelik tutumundan

Hiç memnun değilim Memnun değilim Kararsızım Memnunum Çok memnunum

5. İşletmedeki eğitim sürecine ait faaliyetlerden ( eğitim ihtiyacının belirlenmesi,içeriğinin geliştirilmesi, planlaması, yürütülmesi, değerlendirilmesi )

Hiç memnun değilim Memnun değilim Kararsızım Memnunum Çok memnunum

6. İşletmede verilen eğitim programlarının kapsamından

Hiç memnun değilim Memnun değilim Kararsızım Memnunum Çok memnunum

7. İşletmede kendi isteklerim doğrultusunda ekstra eğitim taleplerimin karşılanmasından

Hiç memnun değilim Memnun değilim Kararsızım Memnunum Çok memnunum

8. İşletmedeki eğitim ihtiyaçlarının belirlenmesi için kullanılan yöntemlerden

Hiç memnun değilim Memnun değilim Kararsızım Memnunum Çok memnunum

9. İşletmede eğitim veren kişi yada kurumlardan

Hiç memnun değilim Memnun değilim Kararsızım Memnunum Çok memnunum

10. İşletmede uygulanan eğitim programları için seçilen gün ve saatlerden

Hiç memnun değilim Memnun değilim Kararsızım Memnunum Çok memnunum 